\title{
URGENSI SUMBER DAYA MANUSIA MENUJU APARATUR SIPIL NEGARA POTENSIAL BERBASIS KETANGGUHAN MENTAL-SPIRITUAL
}

\author{
Suhanda. S.Pd. MAP. \\ Widyaiswara Muda Pusdiklat \\ Pegawai Kementrian Pendidikan dan Kebudayaan \\ suhanda.pusbang@gmail.com
}

\begin{abstract}
This article explains the importance of human resource potential as a driving force in a organiasi or bureaucracy. The study was conducted with the literature study with reference to a number of previous studies and related literature. From the study represent the importance of human resources in an organization, institution, or bureaucracy. Primarily in a bureaucratic public sector can be used as a reference for building a strong bureaucracy. Civil Administrative State was instrumental as planners, implementers and supervisors holding general duty of government and national development through the implementation of policies and a professional public service, free from political interference, as well as clean of corruption, collusion, and nepotism in the contribution of performance and service support improving the competitiveness of the Indonesian nation. The quality of human resources (HR) is basically determined not only by mastering science and technology, but also the spiritual-mental toughness in creating the human resource potential
\end{abstract}

Key Words: Human Resources, Bureaucracy, Civil Administrative State, MentalSpiritual

\begin{abstract}
Abstrak
Artikel ini menjelaskan urgensi sumber daya manusia yang potensial sebagai motor penggerak dalam sebuah organiasi atau birokrasi. Kajian ini dilakukan dengan studi pustaka dengan mengacu pada sejumlah kajian terdahulu dan literatur yang terkait. Dari kajian ditunjukkan betapa pentingnya sumber daya manusia dalam sebuah organisasi, lembaga, maupun birokrasi. Utamanya dalam sebuah birokrasisektor publik dapat digunakan sebagai acuan untuk membangun birokrasi yang kuat.Aparatur Sipil Negara sangat berperan sebagai perencana,pelaksana, danpengawaspenyelenggaraan tugasumum pemerintahan danpembangunannasionalmelalui pelaksanaan kebijakan danpelayanan publik yang profesional,bebasdariintervensipolitik, sertabersih dari praktik korupsi, kolusi, dan nepotismedalam kontribusi kinerjanya dan pelayanan yang mendukung peningkatan daya saing bangsa Indonesia. Kualitas sumber daya manusia (SDM) pada dasarnya tidak ditentukan hanya dengan menguasai ilmu pengetahuan dan teknologi, tetapi juga ketangguhan mental-spiritual dalam menciptakan sumber daya manusia yang potensial
\end{abstract}

Kata kunci: Sumber Daya Manusia, Birokrasi, Aparatur Sipil Negara, Mental Spiritual 


\section{Pendahuluan}

Salah satu sumber daya yang penting dalam manajemen atau organisasi yaitu sumber daya manusia atau human resources. Mengingat pentingnya sumber daya manusia, perlu disadari oleh semua tingkatan manajemen. Bagaimanapun canggihnya teknologi saat ini, namun faktor manusia tetap mempunyai peranan penting bagi keberhasilan suatu organisasi. Manajemen sumber daya manusia merupakan bagian yang penting, bahkan dapat dikatakan bahwa manajemen itu pada hakikatnya adalah manajemen sumber daya manusia atau manajemen sumber daya manusia adalah identik dengan manajemen itu sendiri' ${ }^{1}$ Sumber Daya Manusia mempunyai peran yang penting dalam rangka pencapaian tujuan organisasi. Setiap organisasi baik organisasi perusahaan, organisasi social maupun organisasi pemerintah mempunyai tujuan yang dapat dicapai melalui pelaksanaanpekerjaan tertentu dengan mempergunakan seluruh sumber daya yang ada di dalam organisasi.

Instansi pemerintah merupakan suatu organisasi yang mempunyai berbagai ragam tujuan. Aktivitas di dalam instansi pemerintah selalu diarahkan untuk mencapai tujuan yang telah ditetapkan sebelumnya namun kondisi saat ini menunjukkan bahwa sumber daya manusia aparatur yang ada sebagian masih jauh dari apa yang diharapkan. Potret sumber daya manusia aparatur saat ini yang menunjukkan profesionalisme yang rendah, banyaknya praktek KKN yang melibatkan aparatur, pelayanan kepada masyarakat yang berbelit-belit, hidup dalam pola patronklien, kurang kreatif dan inovatif, bekerja berdasarkan juklak dan juknis serta mungkin masih banyak potret negatif lainnya yang intinya menunjukkan bahwa aparatur di Indonesia masih lemah

. Gambaran tersebut memberikan dorongan bagi kita untuk melakukan perubahan pada sumber daya manusia aparatur Indonesia. Menjadi bagian dari pemerintah telah menjadi solusi yang tepat untuk berbagai masalah koordinasi dan pengendalian dalam pemerintahan. Semua pemerintah ingin menggunakan kebijakan publik untuk mencapai perubahan yang kongkrit, pelayanan publik dalam rangka untuk melakukannya. Cara terbaik untuk memobilisasi dukungan untuk perubahan pada lingkungan pemerintah, yaitu membuat instrumen kebijakan yang cenderung mengarah pada hasil yang tepat, bagaimana mengalokasikan sumber daya untuk mendorong dan memungkinkan orang untuk memberikan hasil tersebut, bagaimana untuk menggunakan tanggung jawab organisasi dan akuntabilitas untuk pengiriman, dan cara mengevaluasi dan belajar dari pengalaman untuk lebih baik pada waktu yang akan datang 2 . Dalam reformasi birokrasi, pada dasarnya diperlukan sumber daya manusia yang mampu memberikan pelayanan yang optimal kepada masyarakat.

1Zainun, Buchari. Manajemen Sumber Daya Manusia Indonesia, (Jakarta: PT Gunung Agung, 2001), hal. 17

${ }^{2}$ Clara Rigg and Sue Ricahrds. Action Learning, Leadership and Organizational Development in Public Service. (Taylor and Francis Group: Routledge, 2006). hal. 15

RI'AYAH, Vol. 01, No. 02 Juli-Desember 2016 
Meskipun birokrasi publik memiliki ciri-ciri yang berbeda dengan organisasi bisnis, tetapi dalam menjalankan misi, tujuan dan programnya menganut prinsip-prinsip efisiensi, efektivitas dan menempatkan masyarakat sebagai stakeholder yang harus dilayani secara optimal.

Pengembangan sumber daya manusia dalam instansi pemerintah harus ditangani secara serius. Pengelolaan sumber daya manusia yang baik akan berdampak pada kestabilan instansi pemerintah dan upaya pencapaian tujuan dan sasaran instansi pemerintah itu sendiri. Pegawai Negeri Sipil adalah penghasil kerja bagi instansi pemerintah.Setiap pekerjaan dalam organisasi selalu dilaksanakan oleh pegawai. Berhasil tidaknya suatu instansi pemerintah ditentukan oleh pegawai yang melakukan pekerjaan sehingga perlu adanya balas jasa terhadap pegawai sesuai dengan kinerjanya. Seorang pegawai perlu diperlakukan dengan baik agar pegawai tetap bersemangat dan berprestasi dalam bekerja.

Pimpinan dalam instansi pemerintah dituntut untuk memperlakukan pegawai dengan baik dan memandang mereka sebagai manusia yang mempunyai kebutuhan baik materi maupun non materi. Pimpinan dalam instansi pemerintah juga perlu mengetahui, menyadari dan berusaha memenuhi kebutuhan pegawainya, sehingga pegawai dapat bekerja sesuai dengan harapan instansi pemerintah itu sendiri.Secara manajemen, pengembangan sumber daya sebagai kapital harusterus-menerus dikembangkan, sehingga mampu memberi kontribusi pada pencapaian tujuan organisasi. Hanya dengan pegawai yang tepat yang ditempatkan dalam jabatannya dan memperoleh pelatihan, peralatan, struktur, insentif dan akuntabilitas untuk bekerja secara efektif, maka sangat mungkin organisasi tersebut akan berhasil ${ }^{3}$.

Sebenarnya potensi dasar yang ada pada manusia sangat penting sebagai karunia yang diberikan Tuhan nya untuk menjalankan tugasnya sebagai khalifah di muka bumi.Suatu kedudukan yang istimewa di dalam alam semesta ini. Manusia tidak akan mampu menjalankan amanahnya sebagaiseorang khalifah, tidak akan mampu mengemban tanggung jawabnya jikalau ia tidak dilengkapi dengan potensi-potensi tersebut dan mengembangkannya sebagai sebuah kekuatan dan nilai lebih manusia dibandingkan makhluk lainnya ${ }^{4}$.Karena itu, Islam memandang manusia sangat mulia dengan sumber ajarannya yaitu alQur,an. Ia telah memotret manusia dalam bentuknya yangutuh dan menyeluruh. Sifat-sifat Ilahiah yang ada pada diri manusia sesunggunya pancaran dari sifatsifat Allah yang terpuji ${ }^{5}$. Islam menghendaki manusia berada pada tatanan yang tinggi dan luhur. Oleh karena itu manusia dikaruniai akal, perasaan, dan tubuh

3U.S. Office of Personnel Management. Strategic Human Resources Management, (Washington, D.C: U.S. Office of Personnel Management, 1999), hal. 3.

${ }^{4}$ HasanLanggulung,. Manusia dan Pendidikan Suatu Analisa Psikologi dan Pendidikan. (Jakarta : Pustaka Al-Husna, 1989), h. 57.

${ }^{5}$ Djaelany Haluti, Islam Dan Manajemen Sumber Daya Manusia Yang Berkualitas, Jurnal Irfani, Volume. 10 Nomor 1, Juni 2014. hal. 68.

RI'AYAH, Vol. 01, No. 02 Juli-Desember 2016 
yang sempurna. Islam, melalui ayat-ayat al-Qur.an telah mengisyaratkan tentang kesempurnaan diri manusia 6 .

Untuk itu jika dilihat dalam berbagai kajian bahwa, kritik terhadap semakin buruknya kinerja, produktivitas, serta motivasi aparatur mulai dari pemerintah level atas hingga pemerintah level paling bawah (kepala kampung) sebagai penyedia layanan (service provider) bagi masyarakat antara lain di sebabkan karena kurangnya kesiapan Sumber Daya Manusia bagi aparatur pemerintahan karena pada dasarnya setiap diri ini mampu menjadi Sumber Daya Manusia potensial bila dibina dan tumbuh dengan sebagaimana mestinya. Tentu saja dalam hal ini terjadi bila individu menjadi aparatur sipil negara dimulai dari kegiatan prajabatan dimana sebenarnya penanaman nilai-nilai moral dan berbagai aspek ditanamkan dalam hal itu. Oleh karena itu, diharapkan pemerintah dapat mengambil langkah-langkah konkrit untuk perbaikan kinerja aparatur pemerintah sebagai penyedia layanan terhadap masyarakat melalui peningkatan kualitas sumber daya aparatur pemerintahan secara profesional dan terencana serta adanya kebijakan-kebijakan khusus dalam meningkatkan kualitas sumber daya aparatur pemerintahan sebagai penyedia layanan(service provider) tersebut.

Maka tulisan ini dimaksudkan untuk mendeskripsikan fenomena dan pengantar pentingnya sumber daya manusia khususnya sektor publik sehingga dapat digunakan sebagai acuan untuk membangun birokrasi yang kuat dalam memberi pelayanan yang mendukung peningkatan daya saing bangsa Indonesia serta juga berusaha menyelaraskan menurutaspek spiritualterkaitsumber daya manusia yang potensial yang sebagian besar aparatur pemerinatahan dan masyarakat indonesia beragama Islam.

\section{Tinjauan Pustaka}

\section{Sumber daya Manusia}

Manajemen sumber daya manusia timbul sebagai suatumasalah baru pada sekitar tahun 1960-an, sebelum itu kurang lebih pada tahun 1940-an yang mendominasi adalah manajemen personalia. Antara keduanya jelas terdapat perbedaandidalam ruanglingkup dan tingkatannya. Manajemen sumber daya manusia mencakuphal-hal yang berkaitan dengan pembinaan, penggunaan dan perlindungan sumber daya manusia; sedangkan manajemen personalia lebih banyak berkaitan dengan sumber daya manusia yang berada dalam suatu entitas, yang umum dikenal dengan sektor modern itu7. Manajemen sumber daya manusia merupakan salah satu bidang dari manajemenumum yang meliputi segi-segi perencanaan, pengorganisasian, pelaksanaan dan

\footnotetext{
6Seperti yang disebutkan dalam Q.S. at-Tin/95:4 yang berbunyi “Sesungguhnya Kami telah menciptakan manusia dalam bentuk yang sebaik-baiknya".

7Faustino Cardoso Gomes, Manajemen Sumber Daya Manusia, (Yogyakarta: Penerbit Andi, 2003), hal. 2
}

RI'AYAH, Vol. 01, No. 02 Juli-Desember 2016 
pengendalian. Karena sumber daya manusia dianggap semakin penting peranannya dalam pencapaian tujuan maka berbagai pengalaman dan hasil penelitian dalam bidang sumber daya manusia (SDM) dikumpulkan secara sistematis dalam apa yang disebut dengan Manajemen sumber daya manusia.Istilah "manajemen"mempunyai arti sebagai kumpulan pengetahuan tentang bagaimana seharusnya memanage (mengelola) sumber dayamanusia8.

Manusia sebagai sumber daya adalah penggerak organisasi, organisasi tidak akan berfungsi tanpa sumber daya manusia. Bisa dikatakan manusia membutuhkan organisasi dansebaliknya organisasi membutuhkan manusia. Secara ekstrim dapat dikatakan organisasi adalahmanusia. Sumber daya manusia merupakan semua manusia yang terlibat di dalam suatu organisasi dalam mengupayakan terwujudnya tujuan oragnisasi ${ }^{9}$. Sumber Daya Manusia pada intinya terbagi menjadi secara makro dan mikro. Pengertian secara makro adalah manusia sebagai penduduk atau warga negara suatu negara atau dalam batas wilayah tertentu yang sudah memasuki angkatan kerja, baik yang sudah maupun belum memperoleh pekerjaan (lapangan kerja). Pengertian SDM dalam arti mikro seacara sederhana adalah manusia atau orang yang bekerja atau menjadi anggota suatu oragnisasi yang disebut personil, pegawai, karyawan, pekerja, tenaga kerja.Jadi sumber daya manusia adalah semua orang yang terlibat yang bekerja bekerja untuk mencapai tujuan organisasi ${ }^{10}$.

Pencapaian keoptimalan sumber daya manusia yang optimal diperlukan pengelolaan sumber daya manusia yang tepat. Pengelolaan sumber daya manusia berarti penyiapan dan pelaksanaan suatu rencana yang terkoordinasi untuk menjamin bahwa sumber daya manusia yang ada dapat dimanfaatkan dengan sebaik-baiknya untuk mencapai tujuan organisasi ${ }^{11}$. Sedangkan perencanaan SDM adalah merencanakan tenaga kerja agar sesuai dengan kebutuhan perusahaan serta efektif dan efisien dalam terwujudnya tujuan ${ }^{12}$. Jadi perencanaan sumber daya manusia adalah proses menetapkan estimasi atau perkiraan untuk memperoleh sumber daya manusia agar sesuai dengan kebutuhan organisasi sekarang dan pengembangannya di masa akan datang.

\section{Manajemen Sumber Daya Manusia}

Hall T. Douglas dan Goodale G. James mengemukakan bahwa

\footnotetext{
8 Veithzal Rivai, Manajemen Sumber Daya Manusia Untuk Perusahaan dari Teori ke Praktik, PT Raja Grafindo Persada,Jakarta, 2005. hal. 1

9Sayuti Hasibuan. Manajemen sumber daya manusia: pendekatan non sekuler, (Surakarta: Muhammadiyah University Press, 2000), hal. 3

${ }^{10}$ Hadari Nawawi. Manajemen Sumber Daya Manusia Untuk Bisnis yang Kompetitif, (Yogyakarya: Gadjah Mada University Press, 2003), hal 37

11Sayuti... hal. 1

12Ibid...hal.2.
}

RI'AYAH, Vol. 01, No. 02 Juli-Desember 2016 
Manajemen sumber daya manusia adalah: "Human Resource Managementis the prosses through hican optimal fit is achieved among the employee, job, organization, and environment so that employeesreachtheirdesiredlevelofsatisfactionand performance and the organization meet sit's goals"13.

Manajemen sumber daya manusia adalah suatu proses melalui mana kesesuaian optimal diperolehdiantarapegawai,pekerjaan organisasi dan lingkungansehingga para pegawai mencapai tingkat kepuasan dan performansi yang mereka inginkan dan organisasi memenuhi tujuannya. Sedangkan Menurut Edin Flippo "Personal management is the planning, organizing, directing, and controlling of the procurement, development, compensation, integration, maintenance, and separation of human resources to the end that individual, organizational and societalobjectives are accomplished ${ }^{14}$

Manajemen sumber daya manusia adalah perencanaan, pengorganisasian, pengarahandan pengendalian atas pengadaan tenagakerja,pengembangan, kompensasi, integrasi, pemeliharaan, dan pemutusan hubungan kerja dengan sumber daya manusia untuk mencapai sasaran perorangan, organisasi, dan masyarakat. Manajemen sumber daya manusia adalah perencanaan, pengorganisasian, pengaraha ndan pengendalian atas pengadaan tenaga kerja,pengembangan, kompensasi, integrasi, pemeliharaan, dan pemutusan hubungan kerja dengan sumber daya manusia untuk mencapai sasaran perorangan, organisasi, dan masyarakat.

Selanjutnya Manajemen sumber daya manusia pada era informasi ini, menurut Dessler yaitu: "Strategic Human Resource Management is the linking of Human Resource Management with strategic role and objectives in order to improve business performance and develop organizational cultures and foster innovation and flexibility ${ }^{15}$.

Terlihat bahwa para pimpinan organisasi harus mengaitkan pelaksanaan manajemen sumber daya manusia dengan strategi organisasi untukmeningkatkan kinerja serta mengembangkan budaya organisasi yang akan mendukung penerapan inovasi dan fleksibilitas. Di era persaingan global yang ketat, sumber daya manusia dianggap sebagai salah satu faktor yang paling penting memainkan peran utama dalam menjaga keberlanjutan organisasi, kredibilitas serta penciptaan kepercayaan publik. Penekanan pada sumber daya manusia sebagai

\footnotetext{
${ }^{13}$ Hall T. Douglas. \& James Good ale G, Human Resources Management, Strategy, Design and Impelementation, (Scott Foresmanand Company: Glenview, 1986), hal. 6.

${ }^{14}$ Malayu Hasibuan, S. P. Manajemen Sumber Daya Manusia. (Jakarta: PT. Bumi Aksara, 2000), hal. 11

${ }^{15}$ G. Dessler. Manajemen Sumber Daya Manusia. Jilid 2. Edisi Kesembilan. (Jakarta: PT Indeks Kelompok Gramedia, 2003), hal. 10.
}

RI'AYAH, Vol. 01, No. 02 Juli-Desember 2016 
modal berharga dalam organisasi mencerminkan pekanan lebih pada sumber daya tak berwujud daripada yang nyata.

Dari beberapa ulasan yang telah disampaikan menunjukkan kenyataan bahwa sumber daya manusia merupakan unsur utama atau faktor sentral di dalam sebuah organisasi apapun bentuknya. Baik itu organisasi profit, seperti perusahaan dan industri maupun non profit seperti instansi pemerintah dan organisasi sosial dan kemanusiaan.

Bagi sektor publik, tanggung jawab besar birokrasi dalam memberi pelayanan kepada masyarakat harus didukung oleh Sumber Daya Manusia (SDM) aparatur yang profesional dan kompeten. Dalam konteks reformasi birokrasi, sumber daya manusia merupaka salah satu pilar perbaikan di samping aspek kelembagaan dan sistem. Utilisasi SDM aparatur secara efektif dan efisien menjadi fungsi utama Manajemen SDM(MSDM) bagi birokrasi mulai dari perencanaan hingga tahap terminasi SDM.

Sebagaimana terdapat dalam berbagai literatur manajemen, pencapaian tujuan organisasi secara manajerial diawali dengan fungsi perencanaan ${ }^{16}$. Keterlibatan aparatur dalam perencanaan memiliki peran signifikan terutama berkaitan dengan sikap dan perilakunya. Sikap aparatur yang terlibat dalam perencanaan berperan penting bagi pencapaian kinerja organisasi sektor publik di samping adanya pengaruh sejumlah variabel teknis lainnya. Jika dalam tahap perencanaan SDM bermutu mempunyai peran penting dalam mencapai target yang ditetapkan, maka proses manajerial birokrasi selanjutnya dalam bentuk pengarahan, pelaksanaan, dan evaluasi pun harus didukung oleh aparat yang berkualitas.

Dalam konteks yang demikian itulah, tantangan untuk menjawab masalah peningkatan mutu aparat. Hingga saat ini mutu aparat birokrasi dalam memberikan layanan publik di Indonesia masih menjadi persoalan yang sangat serius. Masyarakat sebagai pengguna layanan birokrasi acapkali mengeluhkan mutu aparat dalam menjalankan fungsinya. Berbagai bentuk keluhan muncul mulai dari proses pelayanan, waktu yang dibutuhkan dalam penyelesaian urusan, sikap dan perilaku aparat, hingga berkaitan dengan kualitas hasil layanan. Permasalahan serius yang tak kunjung teratasi tersebut pada ahirnya memposisikan Indonesia sebagai negara yang tidak kondusif bagi pelayanan publik.Peran MSDM di sektor publik menjadi sangat kritis dan berbeda kondisinya dengan sektor privat ${ }^{17}$. Secara historis konsep-

16Ivancevich JM, Donnely JH Jr. and Gibson JL. Management Principlesand Functions, 4th ed. New Delhi: Richaerd D. Irwin, Inc. 2004, hal. 66

17P.Boselie., Paauwe, J. and Richardson, R. Human resource management, institutionalization and organizational performance:A comparison of hospitals, hotels and local government.The International Journal of Human Resource Management 14(8), 2003, hal. 1412.

RI'AYAH, Vol. 01, No. 02 Juli-Desember 2016 
konsep yang berkembang dalam MSDM memang berawal dari kegiatan usaha sektor privat. Selain budaya, iklim organisasi yang tidak kondusif dan nilai-nilai manajerial yang tidak relevan dengan perubahan menjadi ganjalan birokrasi dalam mencapai efektifitas organisasi

Sangat penting artinya bagi dunia ilmu pengetahuan dan praktisi untuk menguraikan SDM dalam budaya, iklim organisasi dan nilai-nilai manajerial khas birokrasi yang berbeda dengan perusahaan yang merepresentasikan sektor privat. Dengan keyakinan terhadap pandangan bahwa budaya dan iklim organisasi serta nilai-nilai manajerial dapat mendukung pencapaian keunggulan bersaing organisasi

\section{Sumber Daya Manusia Birokrasi: Aparatur Sipil Negara}

Aparatur Sipil Negara yang selanjutnya disingkat ASN adalah profesi bagi pegawai negeri sipil dan pegawai pemerintah dengan perjanjian kerja yang bekerja pada instansi pemerintah ${ }^{18}$.

Peran Aparatur Sipil Negara dalam UU ASN nomor 5 tahun 2014 menyebutkan Pegawai ASN berperan sebagai perencana,pelaksana, danpengawaspenyelenggaraan tugasumum pemerintahan danpembangunannasionalmelalui pelaksanaan kebijakan danpelayanan publik yang profesional,bebasdariintervensipolitik,sertabersih dari praktik korupsi, kolusi, dan nepotisme ${ }^{19}$. Sedangkan nilai Dasar ASN, meliputi ${ }^{20}$ :

\begin{tabular}{|c|l|}
\hline a. & memegang teguh ideologi Pancasila; \\
\hline b. & $\begin{array}{l}\text { Setia dan mempertahankan Undang-Undang Dasar Negara Republik } \\
\text { Indonesia Tahun } 1945 \text { serta pemerintahan yang sah }\end{array}$ \\
\hline c. & mengabdi kepada negara dan rakyat Indonesia; \\
\hline d. & Menjalankan tugas secara profesional dan tidak berpihak; \\
\hline e. & membuat keputusan berdasarkan prinsip keahlian \\
\hline f. & menciptakan lingkungan kerja yang non diskriminatif; \\
\hline g. & memelihara dan menjunjung tinggi standar etika yang luhur; \\
\hline h. & Mempertanggungjawabkan tindakan dan kinerjanya kepada publik; \\
\hline i. & $\begin{array}{l}\text { memiliki kemampuan dalam melaksanakan kebijakan dan program } \\
\text { pemerintah }\end{array}$ \\
\hline j. & $\begin{array}{l}\text { memberikan layanan kepada publik secara jujur, tanggap, cepat, tepat, } \\
\text { akurat, berdaya guna, berhasil guna, dan santun; }\end{array}$ \\
\hline k. & mengutamakan kepemimpinan berkualitas tinggi \\
\hline l. & menghargai komunikasi, konsultasi, dan kerjasama \\
\hline m. & mengutamakan pencapaian hasil dan mendorong kinerja pegawai; \\
\hline n. & mendorong kesetaraan dalam pekerjaan; \\
\hline
\end{tabular}

18Tertuang dalam pasal 1 UU ASN no 5 tahun 2014 tentang Aparatur Sipil Negara

${ }^{19}$ Tertuang dalam pasal 12 UU ASN no 5 tahun 2014

20Tertuang dalam pasal 4 UU ASN no 5 tahun 2014

RI'AYAH, Vol. 01, No. 02 Juli-Desember 2016 
o. Meningkatkan efektivitas sistem pemerintahan yang demokratis sebagai perangkat sistem karier.

Adapun Kode etik dan kode perilaku Apatur Sipil Negara21:

\begin{tabular}{|c|l|}
\hline a. & $\begin{array}{l}\text { Melaksanakan tugasnya dengan jujur, bertanggung jawab, dan } \\
\text { berintegritas tinggi; }\end{array}$ \\
\hline b. & melaksanakan tugasnya dengan cermat dan disiplin \\
\hline c. & Melayani dengan sikap hormat, sopan, dan tanpa tekanan; \\
\hline d. & $\begin{array}{l}\text { Melaksanakan tugasnya sesuai dengan ketentuan peraturan perundang- } \\
\text { undangan; }\end{array}$ \\
\hline e. & $\begin{array}{l}\text { melaksanakan tugasnya sesuai dengan perintah atasan atau Pejabat yang } \\
\text { Berwenangs ejauh tidak bertentangan dengan ketentuan peraturan } \\
\text { perundang-undangan dan etika pemerintahan; }\end{array}$ \\
\hline f. & Menjaga kerahasiaanya menyangkut kebijakan negara \\
\hline g. & $\begin{array}{l}\text { Menggunakan kekayaan dan barang milik negara secara } \\
\text { bertanggungjawab, efektif, dan efisien; }\end{array}$ \\
\hline h. & $\begin{array}{l}\text { menjaga agar tidak terjadi konflik kepentingan dalam melaksanakan } \\
\text { tugasnya; }\end{array}$ \\
\hline i. & $\begin{array}{l}\text { memberikan informasi secara benar dan tidak menyesatkan kepada pihak } \\
\text { lain yang memerlukan informasi terkait kepentingan kedinasan; }\end{array}$ \\
\hline j. & $\begin{array}{l}\text { Tidak menyalahgunakan informasi intern negara, tugas, status, } \\
\text { kekuasaan, dan jabatannya untuk mendapat atau mencari keuntungan } \\
\text { atau manfaat bagi diri sendiri atau untuk orang lain; }\end{array}$ \\
\hline k. & $\begin{array}{l}\text { memegang teguh nilai dasar ASN dan selalu } \\
\text { menjagareputasidanintegritasASN; }\end{array}$ \\
\hline l. & $\begin{array}{l}\text { melaksanakan ketentuan peraturan perundang- undangan mengenai } \\
\text { disiplin Pegawai ASN. }\end{array}$ \\
\hline
\end{tabular}

Setiap Pegawai ASN memiliki hak dan kesempatan untuk mengembangkan kompetensi. Pengembangankompetensitersebut antara lain melalui pendidikandan pelatihan, seminar, kursus, dan penataran 22 .

PeraturanPemerintah Nomor101Tahun2000tentangPendidikan dan Pelatihan Jabatan Pegawai Negeri Sipil (PNS), yang dimaksud dengan Pendidikan dan Pelatihan Jabatan Pegawai Negeri Sipil yang selanjutnya disebut Diklat adalah proses penyelenggaran belajar mengajar dalam rangka meningkatkan kemampuan Pegawai Negeri Sipil23. Selanjutnya Tujuan dan sasaran diklat, diklat bertujuan ${ }^{24}$ :

\footnotetext{
21Tertuang dalam pasal 5 UU ASN no 5 tahun 2014

22Tertuang dalam pasal 5 UU ASN no 5 tahun 2014

23Tertuang dalam Peraturan Pemerintah Nomor 101 Tahun 2000 tentang Pendidikan dan Pelatihan Jabatan Pegawai Negeri Sipil (PNS) pasal 1

24Tertuang dalam Peraturan Pemerintah Nomor 101 Tahun 2000 tentang Pendidikan dan Pelatihan Jabatan Pegawai Negeri Sipil (PNS) pasal 2

RI'AYAH, Vol. 01, No. 02 Juli-Desember 2016
} 
a. Meningkatkan pengetahuan, keahlian, keterampilan, dan sikap untuk melaksanakan tugas jabatan secara profesional dengan dilandasi kepribadian dan etika PNS sesuai dengan kebutuhan instansi;

b. Menciptakan aparatur yang mampu berperan sebagai pembaharu dan perekat persatuan bangsa;

c. Memantapkan sikap dan semangat pengabdian yang berorientasi pada pelayanan, pengayoman, dan pemberdayaan masyaraakat;

d. Menciptakan kesamaan visi dinamika pola pikir dalam melaksanakan tugas pemerintahan umum dan pembangunan demi terwujudnya kemerintahan yang baik

Adapun sasaran diklat adalah terwujudnya PNS yang memiliki kompetensi yang sesuai dengan persyaratan jabatan masing-masing ${ }^{25}$. Dan Diklat prajabatan merupakan syarat pengangkatan CPNS menjadi PNS yang terdiri dari 26 :

a. Diklat Prajabatan golongan I untuk PNS golongan 1;

b. Diklat Prajabatan golongan II untuk PNS golongan II;

c. Diklat Prajabatan golongan III untuk PNS golongan III.

Salah satu jenis Diklat yang strategis untuk mewujudkan PNS sebagai bagian dari ASN menjadi profesional seperti tersebut di atas adalah Diklat Prajabatan.Diklat ini dilaksanakan dalam rangka membentuk nilai-nilai dasar profesi PNS. Kompetensi inilah yang kemudian berperan dalam membentuk karakter PNS yang kuat, yaitu PNS yang mampu bersikap dan bertindak profesional dalam melayani masyarakat.

Keputusan Kepala Lembaga Administrasi Negara Nomor 38 Tahun 2014 tentang Pedoman Penyelenggaraan Pendidikan dan Pelatihan Prajabatan Calon Pegawai Negeri Sipil Golongan III27. Bahwa untuk membentuk PNS profesional, dibutuhkan pembaharuan atas pola penyelenggaraan diklat yang ada saat ini dan yang didukung oleh semua pihak. Praktik penyelenggaraan Diklat Prajabatan dengan pola pembelajaran klasikal yang didominasi dengan metode ceramah, menunjukkan bahwa tidak mudah untuk membentuk nilai-nilai dasar profesi PNS, terutama proses internalisasi pada diri masing-masing peserta. Berdasakan pertimbangan akan hal tersebut maka dilakukan inovasi dalam penyelenggaraan Diklat Prajabatan yang memungkinkan peserta untuk mampu menginternalisasikan nilai-nilai dasar profesi PNS

25Tertuang dalam Peraturan Pemerintah Nomor 101 Tahun 2000 tentang Pendidikan dan Pelatihan Jabatan Pegawai Negeri Sipil (PNS) pasal 3

26Tertuang dalam Peraturan Pemerintah Nomor 101 Tahun 2000 tentang Pendidikan dan Pelatihan Jabatan Pegawai Negeri Sipil (PNS) pasal 5 ayat (1) dan (2)

27Tertuang dalam latar belakang Keputusan Kepala Lembaga Administrasi Negara Nomor 38 Tahun 2014 tentang Pedoman Penyelenggaraan Pendidikan dan Pelatihan Prajabatan Calon Pegawai Negeri Sipil Golongan III

RI'AYAH, Vol. 01, No. 02 Juli-Desember 2016 
dengan cara mengalami sendiri dalam penerapan dan aktualisasi pada tempat tugas/tempat magang, sehingga peserta merasakan manfaatnya secara langsung. Dengan demikian nilai-nilai dasar profesi PNS tersebut terpatri kuat dalam dirinya. Melalui pembaharuan Diklat Prajabatanini diharapkan dapat menghasilkan PNS yang profesional, yang dewasa ini sangat dibutuhkan untuk mengelola segala prakondisi dan sumberdaya pembangunan yang ada, sehingga dapat mempercepat peningkatan daya saing bangsa. Dengan tujuan dan sasaran bahwa Penyelenggaraan Diklat Prajabatan bertujuan untuk membentuk PNS yang profesional yaitu PNS yang karakternya dibentuk oleh nilai-nilai dasar profesi PNS, sehingga mampu melaksanakan tugas dan perannya secara profesional sebagai pelayan masyarakat.

Sasaran penyelenggaraan Diklat Prajabatan adalah terwujudnya PNS yang profesional. Sehingga kompetensi yang harus dibangun dalam Diklat Prajabatan CPNS Golongan III adalah kompetensi PNS sebagai pelayan masyarakat yang profesional, yang diindikasikan dengan kemampuan mengaktualisasikan lima nilai dasar yaitu:

\begin{tabular}{|c|l|}
\hline a. & $\begin{array}{l}\text { Kemampuan mewujudkan akuntabilitas dalam melaksanakan tugas } \\
\text { jabatannya; }\end{array}$ \\
\hline b. & $\begin{array}{l}\text { kemampuan mengedepankan kepentingan nasional dalam pelaksanaan } \\
\text { tugas jabatannya; }\end{array}$ \\
\hline c. & $\begin{array}{l}\text { kemampuan menjunjung tinggi standar etika publik dalam } \\
\text { pelaksanaan tugas jabatannya; }\end{array}$ \\
\hline d. & $\begin{array}{l}\text { Kemampuan berinovasi untuk peningkatan mutu pelaksanaan tugas } \\
\text { jabatannya; }\end{array}$ \\
\hline e. & $\begin{array}{l}\text { kemampuan untuk tidak korupsi dan mendorong percepatan } \\
\text { pemberantasan korupsi dilingkungan instansinya. }\end{array}$ \\
\hline
\end{tabular}

Perbedaan kompetensi yang dibangun untuk diklat prajabatan CPNS Golongan I dan II dan Diklat Prajabatan CPNS Golongan III adalah pada diklat prajabatan CPNS Golongan III memiliki kemampuan menganalisis sedangkan pada diklat prajabatan CPNS Golongan I dan II tidak dibekali kemampuan analisis. Sekilas flash back ketika Pegawai dalam suatu instansi atau birokrasi merupakan sebagai sumber daya manusia, dan sebagai hasil proses seleksi harus dikembangkan agar kemampuan mereka dapat mengikuti perkembangan instansi/birokarasi. Di dalam suatu organisasi pemerintah baik itu Departemen atau Lembaga non Departemen ada suatu unit kerja atau bagian yang mempunyai tugas untuk pengembangan atau peningkatan komptensi tenagnya baik bagi pegawai baru maupun pegawai lama yang lebih populer disebut PusatPendidikan dan Pelatihan Pegawai (PUSDIKLAT).

Salah satu pendidikan bagi pegawai baru adalah diklat Prajabatan. Pengembangan sumber daya manusia dapat diartikan sebagai

RI'AYAH, Vol. 01, No. 02 Juli-Desember 2016 
upaya mempersiapkan pegawai (sumber daya manusia) agar dapat bergerak dan berperan dalam organisasi sesuai dengan pertumbuhan, perkembangan dan perubahan suatu organisasi melalui diklat/pelatihanpelatihan yang terkait. Oleh sebab itu, kegiatan pengembangan pegawai dirancang untuk memperoleh pegawai-pegawai yang mampu berprestasi dan fleksibel untuk suatu organisasi atau instansi dalam geraknya di masa depan.

\section{Sumber Daya Manusia Berkualitas: Islamic Perspective}

Manusia diciptakan oleh Allah untuk ditempatkan pada kedudukan yang mulia. Untuk mempertahankan kedudukannya yang mulia dan manusia dikaruniai dengan akal dan perasaan yang memungkinkannya menerimadan mengembangkan ilmu pengetahuan dan membudayakan ilmu yang dimilikinya.Ini berarti bahwa kedudukan manusia sebagai makhluk yang muliaitu karena akal dan perasaan, ilmu pengetahuan dan kebudayaan yangseluruhnya dikaitkan kepada pengabdian pada Pencipta 28 .

Potensi-potensi yang diberikan kepada manusia pada dasarnya merupakan petunjuk (hidayah). Potensi dasar manusiadapat dibagi tiga yaitu, potensi fitrah, qolb, dan akal29. Allah yang memperuntukkan manusia supaya ia dapat melakukan sikap hidup yang serasi dengan hakekat penciptaannya. Sejalan dengan upaya pembinaan seluruh potensi manusia, Islam melakukan pendidikan dengan melakukan pendekatan yang menyeluruh terhadap wujud manusia, sehingga tidak ada yang tertinggal dan terabaikan sedikitpun, baik dari segi jasmani maupun segi rohani, baik kehidupannya secara mental, dan segala kegiatannya di bumi ini. Islam memandang manusia secara totalitas, mendekatinya atas dasar apa yang terdapat dalam dirinya, berdasar fitrah yang diberikan Allah kepadanya, tidak ada sedikitpun yang diabaikan dan tidak memaksakan apapun selain apa yang dijadikannya sesuai dengan fitrahnya. Petunjuk dengan jelas bahwa dalam rangka mencapai pendidikan Islam mengupayakan pembinaan seluruh potensi secara serasi dan seimbang ${ }^{30}$.

Potensi yang ada pada manusia sangat penting sebagai karunia yang diberikan Allah untuk menjalankan tugasnya sebagai khalifah di muka bumi. Suatu kedudukan yang istimewa di dalam alam semesta ini. Manusia tidak akan mampu menjalankan amanahnya sebagai seorang khalifah, tidak akan mampu mengemban tanggung jawabnya jikalau ia tidak dilengkapi dengan potensi-potensi tersebut dan

28Zakiah Daradjat, Ilmu Pendidikan Islam, Cet. III, (Jakarta: Bumi Aksara,1996), hal. 3.

${ }^{29}$ Muhaimin dan Abdul Mujib, Pemikiran Pendidikan Islam; Kajian Filosofis dan Kerangka Dasar Operasionalisasinya, Cet. I, (Bandung: Tri Genda Karya, 1993), hal. 10-11.

${ }^{30}$ Abuddin Nata, Filsafat Pendidikan Islam (Cet. I; Jakarta: Logos Wacana Ilmu, 1997), hal. 51.

RI'AYAH, Vol. 01, No. 02 Juli-Desember 2016 
mengembangkannya sebagai sebuah kekuatan dan nilai lebih manusia dibandingkan makhluk lainnya ${ }^{31}$. Artinya, jika kualitas SDM manusianya berkualitas maka ia dapat mempertanggungjawabkan amanahnya sebagai seorang khalifah dengan baik. Kualitas SDM ini tentu saja tak hanya cukup dengan menguasai ilmu pengetahuan dan teknologi (iptek), tetapi juga pengembangan nilai-nilai rohanispiritual, yaitu berupa iman dan taqwa (imtaq). Bahwa pengembangan SDM sangat penting. Kualitas SDM tidak akan sempurna tanpa ketangguhan mental-spiritual keagamaan.

Sumber daya manusia yang mempunyai dan memegang nilai-nilai agama akan lebih tangguh secararrohaniah. Dengan demikian akan lebih mempunyai tanggung jawab spiritual terhadap ilmu pengetahuan serta teknologi. Sumber daya manusia yang tidak disertai dengan kesetiaan kepada nilai-nilai keagamaan, hanya akan membawa manusia ke arah pengejaran kenikmatan duniawi atau hedonisme belaka. Dan jika semangat hedonisme sudah menguasai manusia, bisa diramalkan yang terjadi adalah eksploitasi alam sebesar-besarnya tanpa rasa tanggung jawab dan bahkan penindasan manusia terhadap manusia lain ${ }^{32}$. Dengan demikian pengembangan SDM berdasarkan konsep Islam adalah membentuk manusia yang berakhlak mulia, yang senantiasa menyembah Allah yang menebarkan rahmat bagi alam semesta dan bertaqwa kepada Allah.Inilah yang menjadi arah tujuan pengembangan SDM menurut konsep Islam.

Dalam teori yang dikembangkan dunia Barat, dikatakan bahwa perkembangan manusia dipengaruhi oleh pembawaan (nativisme). Sebagai lawannya berkembang pula teori yang mengajarkan bahwa perkembangan seseorang ditentukan oleh lingkunganya (empirisme). Sebagai sintesanya dikembangkan teori tersebutmengatakan bahwa perkembangan seseorang itu ditentukan oleh pembawaan dan lingkungannya(konvergensi) ${ }^{33}$.

\section{Kesimpulan}

Sumber daya manusia atau human resources.Mempunyai peran yang sangat penting dalam keberhasilan suatu organisasi sumber daya manusia, perlu disadari oleh semua tingkatan manajemen. Dalam arti dan lingkup demikianlah, sumber daya manusia perlu dikembangkan secara sistemik dan sistematis. Hal tersebut menjadi semakin terasa penting sebab yang kiranya perlu menjadi pemikiran dan upaya pembaruan ke depan adalah perwujudan suatu paradigma dalam penyelenggaraan pelayanan publik yang berkualitas,

${ }^{31}$ Hasan Langgulung...hal. 57. hal. 240-241.

32Wakhudin, Tarmizi Taher; Jembatan Umat, Ulama dan Umara, (Bandung: Granesia, 1998),

${ }^{33}$ Ngalim Purwanto, Psikologi Pendidikan, (Bandung: RemajaRosda Karya, 1992), hal.14-15.

RI'AYAH, Vol. 01, No. 02 Juli-Desember 2016 
dipadukan secara serasi dan proporsional, untuk mewujudkan sebuah pelayanan yang efektif dan efisien. Pengembangan kualitas sumber daya manusia dalam suatu organisasi biasanya dilakukan dengan adanya pendidikan dan pelatihan (diklat). Pengembangan sumber daya manusia tersebut dapat diartikan sebagai upaya mempersiapkan pegawai (sumber daya manusia) agar dapat bergerak dan berperan dalam organisasi sesuai dengan pertumbuhan, perkembangan dan perubahan suatu organisasi melalui diklat/pelatihan-pelatihan yang terkait. Oleh sebab itu, kegiatan pengembangan pegawai dirancang untuk memperoleh pegawai-pegawai yang mampu berprestasi dan fleksibel untuk suatu organisasi atau instansi dalam geraknya di masa depan.

Manajemen sumber daya manusia harus dipandang sebagai suatu sarana untuk memudahkan implementasi mental dan spiritual dalam kegiatan organisasi ataupun birokrasi. Implementasi nilai-nilai spiritual (islamic perspective) berwujud pada difungsikannya Islam sebagai kaedah berfikir dan kaedah amal tolak ukur perbuatan dalam seluruh kegiatan organisasi. Nilai-nilai Islam inilah sesungguhnya yang menjadi nilai-nilai utama organisasi. Dalam implementasi selanjutnya, nilai-nilai Islam ini akan menjadi payung strategis hingga taktis seluruh aktivitas organisasi manajemen Sumber Daya Manusia. Pengembangan SDM berdasarkan konsep spiritual tersebut membentuk manusia yang berakhlak mulia, yang senantiasa menyembah-Nya yang menebarkan rahmat bagi alam semesta dan bertaqwa kepada-Nya.Inilah yang menjadi arah tujuan pengembangan SDM berbasis konsep mental-spiritual.

\section{Daftar Pustaka}

Abdul Aziz ,Hadits dan Ilmu Hadits untuk MA, Semarang: Penerbit Wicaksana,1988

Abuddin Nata, Filsafat Pendidikan Islam, Cet. I; Jakarta: Logos Wacana Ilmu, 1997

Clara Rigg and Sue Ricahrds. Action Learning, Leadership and Organizational Development in Public Service. Routledge, Taylor and Francis Group, 2006

Daradjat, Zakiah, Ilmu Pendidikan Islam, Cet. III, Jakarta: Bumi Aksara,1996

Dessler, G.. Manajemen Sumber Daya Manusia. Jilid 2. Edisi Kesembilan, Jakarta: PT Indeks Kelompok Gramedia, 2003

Douglas, Hall T. \& James Good ale G, Human Resources Management, Strategy, Design and Impelementation, Scott Foresmanand Company,Glenview, 1986

Faustino,Cardoso Gomes, Manajemen Sumber Daya Manusia, Yogyakarta: Penerbit Andi, 2003

Haluti, Djaelany. Islam Dan Manajemen Sumber Daya Manusia Yang Berkualitas, Jurnal Irfani, Volume. 10 Nomor 1, Juni 2014.

Hasibuan, Malayu S. P. Manajemen Sumber Daya Manusia, Jakarta: PT. Bumi Aksara. 2000

Hasibuan, Sayuti. Manajemen sumber daya manusia: pendekatan non sekuler. Surakarta: Muhammadiyah University Press. 2000

RI'AYAH, Vol. 01, No. 02 Juli-Desember 2016 
Ivancevich JM, Donnely JH Jr. and Gibson JL. Management Principlesand Functions, 4th ed. New Delhi: Richaerd D. Irwin, Inc. 2004

Keputusan Kepala Lembaga Administrasi Negara Nomor 38 Tahun 2014 tentang Pedoman Penyelenggaraan Pendidikan dan Pelatihan Prajabatan Calon Pegawai Negeri Sipil Golongan III

Langgulung, Hasan. Manusia dan Pendidikan Suatu Analisa Psikologi dan Pendidikan, Jakarta : Pustaka Al-Husna, 1989.

Muhaimin dan Abdul Mujib, Pemikiran Pendidikan Islam; Kajian Filosofis dan Kerangka Dasar Operasionalisasinya, Cet. I; Bandung: Tri Genda Karya, 1993.

Nawawi, Hadari. Manajemen Sumber Daya Manusia Untuk Bisnis yang Kompetitif, Gadjah Mada University Press Yogyakarya. 2003. Hal 37

Peraturan Pemerintah Nomor 101 Tahun 2000 tentang Pendidikan dan Pelatihan Jabatan Pegawai Negeri Sipil (PNS)

Purwanto, Ngalim . Psikologi Pendidikan, Bandung: Remaja Rosda Karya, 1992.

Rivai, Veithzal, Manajemen Sumber Daya Manusia, Untuk Perusahaan dari Teori ke Praktik, Jakarta: PT Raja Grafindo Persada, 2005

U.S. Office of Personnel Management. Strategic Human Resources Management, Washington, D.C: U.S. Office of Personnel Management, 1999

Undang Undang Aparatus Sipil Negara no 5 tahun 2014

Wakhudin, Tarmizi Taher; Jembatan Umat, Ulama dan Umara, Bandung: Granesia, 1998

Zainun, Buchari, Manajemen Sumber Daya Manusia Indonesia, Jakarta: PT Gunung Agung, 2001. 